\title{
SLC6 neurotransmitter transporter family (version 2019.4) in the IUPHAR/BPS Guide to Pharmacology Database
}

\author{
Stefan Bröer ${ }^{1}$ and Gary Rudnick ${ }^{2}$ \\ 1. Australian National University, Australia \\ 2. Yale University, USA
}

\begin{abstract}
Members of the solute carrier family 6 (SLC6) of sodium- and (sometimes chloride-) dependent neurotransmitter transporters $[29,22,70]$ are primarily plasma membrane located and may be divided into four subfamilies that transport monoamines, GABA, glycine and neutral amino acids, plus the related bacterial NSS transporters 99]. The members of this superfamily share a structural motif of $10 \mathrm{TM}$ segments that has been observed in crystal structures of the NSS bacterial homolog LeuT $\mathrm{Aa}_{\mathrm{a}}$, a Na ${ }^{+}$-dependent amino acid transporter from Aquiflex aeolicus [126] and in several other transporter families structurally related to LeuT45].
\end{abstract}

\section{Contents}

This is a citation summary for SLC6 neurotransmitter transporter family in the Guide to Pharmacology database (GtoPdb). It exists purely as an adjunct to the database to facilitate the recognition of citations to and from the database by citation analyzers. Readers will almost certainly want to visit the relevant sections of the database which are given here under database links.

GtoPdb is an expert-driven guide to pharmacological targets and the substances that act on them. GtoPdb is a reference work which is most usefully represented as an on-line database. As in any publication this work should be appropriately cited, and the papers it cites should also be recognized. This document provides a citation for the relevant parts of the database, and also provides a reference list for the research cited by those parts.

Please note that the database version for the citations given in GtoPdb are to the most recent preceding version in which the family or its subfamilies and targets were substantially changed. The links below are to the current version. If you need to consult the cited version, rather than the most recent version, please contact the GtoPdb curators.

\section{Database links}

SLC6 neurotransmitter transporter family

http://www.guidetopharmacology.org/GRAC/FamilyDisplayForward?familyld=144

Monoamine transporter subfamily

http://www.guidetopharmacology.org/GRAC/FamilyDisplayForward?familyld=176

Transporters

NET 
http://www.guidetopharmacology.org/GRAC/ObjectDisplayForward?objectld=926

DAT

http://www.guidetopharmacology.org/GRAC/ObjectDisplayForward?objectld=927 SERT

http://www.guidetopharmacology.org/GRAC/ObjectDisplayForward?objectld=928 GABA transporter subfamily

http://www.guidetopharmacology.org/GRAC/FamilyDisplayForward?familyld=177

Transporters

GAT1

http://www.guidetopharmacology.org/GRAC/ObjectDisplayForward?objectld=929

GAT2

http://www.guidetopharmacology.org/GRAC/ObjectDisplayForward?objectld=930

GAT3

http://www.guidetopharmacology.org/GRAC/ObjectDisplayForward?objectld=931

BGT1

http://www.guidetopharmacology.org/GRAC/ObjectDisplayForward?objectld=932

TauT

http://www.guidetopharmacology.org/GRAC/ObjectDisplayForward?objectld=933

CT1

http://www.guidetopharmacology.org/GRAC/ObjectDisplayForward?objectld=934

Glycine transporter subfamily

http://www.guidetopharmacology.org/GRAC/FamilyDisplayForward?familyld=178

Transporters

GlyT1

http://www.guidetopharmacology.org/GRAC/ObjectDisplayForward?objectld=935

GlyT2

http://www.guidetopharmacology.org/GRAC/ObjectDisplayForward?objectld=936

ATB $^{0,+}$

http://www.guidetopharmacology.org/GRAC/ObjectDisplayForward?objectld=937

PROT

http://www.guidetopharmacology.org/GRAC/ObjectDisplayForward?objectld=938

Neutral amino acid transporter subfamily

http://www.guidetopharmacology.org/GRAC/FamilyDisplayForward?familyld=179

Transporters

$\mathrm{B}^{0} \mathrm{AT} 1$

http://www.guidetopharmacology.org/GRAC/ObjectDisplayForward?objectld=939

$\mathrm{B}^{0} \mathrm{AT2}$

http://www.guidetopharmacology.org/GRAC/ObjectDisplayForward?objectld=940

$\mathrm{B}^{0} \mathrm{AT3}$

http://www.guidetopharmacology.org/GRAC/ObjectDisplayForward?objectld=941

NTT5

http://www.guidetopharmacology.org/GRAC/ObjectDisplayForward?objectld=942

NTT4

http://www.guidetopharmacology.org/GRAC/ObjectDisplayForward?objectld=943

SIT1

http://www.guidetopharmacology.org/GRAC/ObjectDisplayForward?objectld=944

\section{References}

1. Ablordeppey SY, Altundas R, Bricker B, Zhu XY, Kumar EV, Jackson T, Khan A and Roth BL. (2008) 
Identification of a butyrophenone analog as a potential atypical antipsychotic agent: 4-[4-(4-chlorophenyl)1,4-diazepan-1-yl]-1-(4-fluorophenyl)butan-1-one. Bioorg. Med. Chem. 16: 7291-301 [PMID:18595716]

2. Altenbach RJ, Black LA, Strakhova MI, Manelli AM, Carr TL, Marsh KC, Wetter JM, Wensink EJ, Hsieh GC and Honore $\mathrm{P}$ et al.. (2010) Diaryldiamines with dual inhibition of the histamine $\mathrm{H}(3)$ receptor and the norepinephrine transporter and the efficacy of 4-(3-(methylamino)-1-phenylpropyl)-6-(2-(pyrrolidin-1yl)ethoxy)naphthalen-1-ol in pain. J. Med. Chem. 53: 7869-73 [PMID:20945906]

3. Amberg W, Lange UEW, Ochse M, Pohlki F, Behl B, Relo AL, Hornberger W, Hoft C, Mezler M and Sydor $J$ et al.. (2018) Discovery of Novel Aminotetralines and Aminochromanes as Selective and Competitive Glycine Transporter 1 (GlyT1) Inhibitors. J. Med. Chem. 61: 7503-7524 [PMID:30080045]

4. Andersen PH. (1989) The dopamine inhibitor GBR 12909: selectivity and molecular mechanism of action. Eur. J. Pharmacol. 166: 493-504 [PMID:2530094]

5. Anderson CM, Ganapathy V and Thwaites DT. (2008) Human solute carrier SLC6A14 is the beta-alanine carrier. J. Physiol. (Lond.) 586: 4061-7 [PMID:18599538]

6. Anderson CM, Howard A, Walters JR, Ganapathy V and Thwaites DT. (2009) Taurine uptake across the human intestinal brush-border membrane is via two transporters: H+-coupled PAT1 (SLC36A1) and Na+and $\mathrm{Cl}(-)-$-dependent TauT (SLC6A6). J. Physiol. (Lond.) 587: 731-44 [PMID:19074966]

7. Arunotayanun W, Dalley JW, Huang XP, Setola V, Treble R, Iversen L, Roth BL and Gibbons S. (2013) An analysis of the synthetic tryptamines AMT and 5-MeO-DALT: emerging 'Novel Psychoactive Drugs'. Bioorg. Med. Chem. Lett. 23: 3411-5 [PMID:23602445]

8. Aubrey KR, Mitrovic AD and Vandenberg RJ. (2000) Molecular basis for proton regulation of glycine transport by glycine transporter subtype 1b. Mol. Pharmacol. 58: 129-35 [PMID:10860934]

9. Auerbach $S S$ and DrugMatrix ${ }^{\circledR}$ and ToxFX ${ }^{\circledR}$ Coordinator National Toxicology Program.. National Toxicology Program: Dept of Health and Human Services.

10. Bang-Andersen B, Ruhland T, Jørgensen M, Smith G, Frederiksen K, Jensen KG, Zhong H, Nielsen SM, Hogg S and Mørk A et al.. (2011) Discovery of 1-[2-(2,4-dimethylphenylsulfanyl)phenyl]piperazine (Lu AA21004): a novel multimodal compound for the treatment of major depressive disorder. J. Med. Chem. 54: 3206-21 [PMID:21486038]

11. Belanger AM, Przybylska M, Gefteas E, Furgerson M, Geller S, Kloss A, Cheng SH, Zhu Y and Yew NS. (2018) Inhibiting neutral amino acid transport for the treatment of phenylketonuria. JCl Insight 3: [PMID:30046012]

12. Ben-Daniel R, Deuther-Conrad W, Scheunemann M, Steinbach J, Brust P and Mishani E. (2008) Carbon11 labeled indolylpropylamine analog as a new potential PET agent for imaging of the serotonin transporter. Bioorg. Med. Chem. 16: 6364-70 [PMID:18487050]

13. Bergeron R, Meyer TM, Coyle JT and Greene RW. (1998) Modulation of N-methyl-D-aspartate receptor function by glycine transport. Proc. Natl. Acad. Sci. U.S.A. 95: 15730-4 [PMID:9861038]

14. Betz H, Gomeza J, Armsen W, Scholze P and Eulenburg V. (2006) Glycine transporters: essential regulators of synaptic transmission. Biochem. Soc. Trans. 34: 55-8 [PMID:16417482]

15. Borden LA, Dhar TG, Smith KE, Branchek TA, Gluchowski C and Weinshank RL. (1994) Cloning of the human homologue of the GABA transporter GAT-3 and identification of a novel inhibitor with selectivity for this site. Recept. Channels 2: 207-13 [PMID:7874447]

16. Borden LA, Murali Dhar TG, Smith KE, Weinshank RL, Branchek TA and Gluchowski C. (1994) Tiagabine, SK\&F 89976-A, Cl-966, and NNC-711 are selective for the cloned GABA transporter GAT-1. Eur. J. Pharmacol. 269: 219-24 [PMID:7851497]

17. Boulay D, Pichat P, Dargazanli G, Estenne-Bouhtou G, Terranova JP, Rogacki N, Stemmelin J, Coste A, Lanneau C and Desvignes C et al.. (2008) Characterization of SSR103800, a selective inhibitor of the glycine transporter-1 in models predictive of therapeutic activity in schizophrenia. Pharmacol. Biochem. Behav. 91: 47-58 [PMID:18621075]

18. Brown A, Carlyle I, Clark J, Hamilton W, Gibson S, McGarry G, McEachen S, Rae D, Thorn S and Walker G. (2001) Discovery and SAR of org 24598-a selective glycine uptake inhibitor. Bioorg. Med. Chem. Lett. 11: 2007-9 [PMID:11454468] 
19. Bröer A, Balkrishna S, Kottra G, Davis S, Oakley A and Bröer S. (2009) Sodium translocation by the iminoglycinuria associated imino transporter (SLC6A20). Mol. Membr. Biol. 26: 333-46 [PMID:19657969]

20. Bröer A, Tietze N, Kowalczuk S, Chubb S, Munzinger M, Bak LK and Bröer S. (2006) The orphan transporter v7-3 (slc6a15) is a Na+-dependent neutral amino acid transporter (B0AT2). Biochem. J. 393: 421-30 [PMID:16185194]

21. Bröer S. (2008) Apical transporters for neutral amino acids: physiology and pathophysiology.Physiology (Bethesda) 23: 95-103 [PMID:18400692]

22. Bröer S. (2006) The SLC6 orphans are forming a family of amino acid transporters.Neurochem. Int. 48: 559-67 [PMID:16540203]

23. Böhmer C, Bröer A, Munzinger M, Kowalczuk S, Rasko JE, Lang F and Bröer S. (2005) Characterization of mouse amino acid transporter B0AT1 (slc6a19). Biochem. J. 389: 745-51 [PMID:15804236]

24. Carland JE, Mansfield RE, Ryan RM and Vandenberg RJ. (2013) Oleoyl-L-carnitine inhibits glycine transport by GlyT2. Br. J. Pharmacol. 168: 891-902 [PMID:22978602]

25. Carlier PR, Lo MM, Lo PC, Richelson E, Tatsumi M, Reynolds IJ and Sharma TA. (1998) Synthesis of a potent wide-spectrum serotonin-, norepinephrine-, dopamine-reuptake inhibitor (SNDRI) and a speciesselective dopamine-reuptake inhibitor based on the gamma-amino alcohol functional group. Bioorg. Med. Chem. Lett. 8: 487-92 [PMID:9871604]

26. Carroll FI, Blough BE, Abraham P, Mills AC, Holleman JA, Wolckenhauer SA, Decker AM, Landavazo A, McElroy KT and Navarro HA et al.. (2009) Synthesis and biological evaluation of bupropion analogues as potential pharmacotherapies for cocaine addiction. J. Med. Chem. 52: 6768-81 [PMID:19821577]

27. Carroll FI, Runyon SP, Abraham P, Navarro H, Kuhar MJ, Pollard GT and Howard JL. (2004) Monoamine transporter binding, locomotor activity, and drug discrimination properties of 3-(4-substitutedphenyl)tropane-2-carboxylic acid methyl ester isomers. J. Med. Chem. 47: 6401-9 [PMID:15566309]

28. Caulfield WL, Collie IT, Dickins RS, Epemolu O, McGuire R, Hill DR, McVey G, Morphy JR, Rankovic Z and Sundaram H. (2001) The first potent and selective inhibitors of the glycine transporter type 2. J. Med. Chem. 44: 2679-82 [PMID:11495577]

29. Chen NH, Reith ME and Quick MW. (2004) Synaptic uptake and beyond: the sodium- and chloridedependent neurotransmitter transporter family SLC6. Pflugers Arch. 447: 519-31 [PMID:12719981]

30. Cheng Q, Shah N, Bröer A, Fairweather S, Jiang Y, Schmoll D, Corry B and Bröer S. (2017) Identification of novel inhibitors of the amino acid transporter $\mathrm{B}^{0} \mathrm{AT1}$ (SLC6A19), a potential target to induce protein restriction and to treat type 2 diabetes. Br. J. Pharmacol. 174: 468-482 [PMID:28176326]

31. Clausen RP, Madsen K, Larsson OM, Frølund B, Krogsgaard-Larsen P and Schousboe A. (2006) Structure-activity relationship and pharmacology of gamma-aminobutyric acid (GABA) transport inhibitors. Adv. Pharmacol. 54: 265-84 [PMID:17175818]

32. Cohen-Kfir E, Lee W, Eskandari S and Nelson N. (2005) Zinc inhibition of gamma-aminobutyric acid transporter 4 (GAT4) reveals a link between excitatory and inhibitory neurotransmission. Proc. Natl. Acad. Sci. U.S.A. 102: 6154-9 [PMID:15829583]

33. Coleman JA, Green EM and Gouaux E. (2016) X-ray structures and mechanism of the human serotonin transporter. Nature 532: 334-9 [PMID:27049939]

34. Cubelos B, González-González IM, Giménez C and Zafra F. (2005) The scaffolding protein PSD-95 interacts with the glycine transporter GLYT1 and impairs its internalization. J. Neurochem. 95: 1047-58 [PMID:16271045]

35. Cuboni S, Devigny C, Hoogeland B, Strasser A, Pomplun S, Hauger B, Höfner G, Wanner KT, Eder M and Buschauer A et al.. (2014) Loratadine and analogues: discovery and preliminary structure-activity relationship of inhibitors of the amino acid transporter B(0)AT2. J. Med. Chem. 57: 9473-9 [PMID:25318072]

36. Dai W, Vinnakota S, Qian X, Kunze DL and Sarkar HK. (1999) Molecular characterization of the human CRT-1 creatine transporter expressed in Xenopus oocytes. Arch. Biochem. Biophys. 361: 75-84 [PMID:9882430]

37. Dawson LA and Watson JM. (2009) Vilazodone: a 5-HT1A receptor agonist/serotonin transporter inhibitor 
for the treatment of affective disorders. CNS Neurosci Ther 15: 107-17 [PMID:19499624]

38. Dhar TG, Borden LA, Tyagarajan S, Smith KE, Branchek TA, Weinshank RL and Gluchowski C. (1994) Design, synthesis and evaluation of substituted triarylnipecotic acid derivatives as GABA uptake inhibitors: identification of a ligand with moderate affinity and selectivity for the cloned human GABA transporter GAT-3. J. Med. Chem. 37: 2334-42 [PMID:8057281]

39. Dhar TGM, Nakanishi H, Borden LA and Gluchowski C. (1996) On the bioactive conformation of the GABA uptake inhibitor SK\&F 89976-A. Bioorganic and medicinal chemistry letters 6: 1535 -1540

40. Dodd JR and Christie DL. (2007) Selective amino acid substitutions convert the creatine transporter to a gamma-aminobutyric acid transporter. J. Biol. Chem. 282: 15528-33 [PMID:17400549]

41. Dreyfus N, Myers JK, Badescu VO, de Frutos O, de la Puente ML, Ding C, Filla SA, Fynboe K, Gernert DL and Heinz BA et al.. (2013) Discovery of a potent, dual serotonin and norepinephrine reuptake inhibitor. ACS Med Chem Lett 4: 560-4 [PMID:24900709]

42. Edington AR, McKinzie AA, Reynolds AJ, Kassiou M, Ryan RM and Vandenberg RJ. (2009) Extracellular loops 2 and 4 of GLYT2 are required for $\mathrm{N}$-arachidonylglycine inhibition of glycine transport. J. Biol. Chem. 284: 36424-30 [PMID:19875446]

43. Eulenburg V, Armsen W, Betz $\mathrm{H}$ and Gomeza J. (2005) Glycine transporters: essential regulators of neurotransmission. Trends Biochem. Sci. 30: 325-33 [PMID:15950877]

44. Fish PV, Deur C, Gan X, Greene K, Hoople D, Mackenny M, Para KS, Reeves K, Ryckmans T and Stiff C et al.. (2008) Design and synthesis of morpholine derivatives. SAR for dual serotonin \& noradrenaline reuptake inhibition. Bioorg. Med. Chem. Lett. 18: 2562-6 [PMID:18387300]

45. Forrest LR and Rudnick G. (2009) The rocking bundle: a mechanism for ion-coupled solute flux by symmetrical transporters. Physiology (Bethesda) 24: 377-86 [PMID:19996368]

46. Froimowitz M, Gu Y, Dakin LA, Nagafuji PM, Kelley CJ, Parrish D, Deschamps JR and Janowsky A. (2007) Slow-onset, long-duration, alkyl analogues of methylphenidate with enhanced selectivity for the dopamine transporter. J. Med. Chem. 50: 219-32 [PMID:17228864]

47. Fülep GH, Hoesl CE, Höfner $G$ and Wanner KT. (2006) New highly potent GABA uptake inhibitors selective for GAT-1 and GAT-3 derived from (R)- and (S)-proline and homologous pyrrolidine-2-alkanoic acids. Eur J Med Chem 41: 809-24 [PMID:16766089]

48. Gabernet L, Pauly-Evers M, Schwerdel C, Lentz M, Bluethmann H, Vogt K, Alberati D, Mohler H and Boison D. (2005) Enhancement of the NMDA receptor function by reduction of glycine transporter-1 expression. Neurosci. Lett. 373: 79-84 [PMID:15555781]

49. Gengo PJ, Giuliano F and McKenna KE et al.. (2005) Monoaminergic transporter binding and inhibition profile of dapoxetine, a medication for the treatment of premature ejaculation [abstract]. J Urol 173:

Abstract 878

50. Glennon RA, Lee M, Rangisetty JB, Dukat M, Roth BL, Savage JE, McBride A, Rauser L, Hufeisen S and Lee DK. (2000) 2-Substituted tryptamines: agents with selectivity for 5-HT(6) serotonin receptors. J. Med. Chem. 43: 1011-8 [PMID:10715164]

51. Gomeza J, Armsen W, Betz H and Eulenburg V. (2006) Lessons from the knocked-out glycine transporters. Handb Exp Pharmacol 457-83 [PMID:16722246]

52. Gomeza J, Hülsmann S, Ohno K, Eulenburg V, Szöke K, Richter D and Betz H. (2003) Inactivation of the glycine transporter 1 gene discloses vital role of glial glycine uptake in glycinergic inhibition. Neuron 40: 785-96 [PMID:14622582]

53. Gomeza J, Ohno K, Hülsmann S, Armsen W, Eulenburg V, Richter DW, Laube B and Betz H. (2003) Deletion of the mouse glycine transporter 2 results in a hyperekplexia phenotype and postnatal lethality. Neuron 40: 797-806 [PMID:14622583]

54. Gu H, Wall SC and Rudnick G. (1994) Stable expression of biogenic amine transporters reveals differences in inhibitor sensitivity, kinetics, and ion dependence. J. Biol. Chem. 269: 7124-30 [PMID:8125921]

55. Gu HH, Wall S and Rudnick G. (1996) lon coupling stoichiometry for the norepinephrine transporter in membrane vesicles from stably transfected cells. J. Biol. Chem. 271: 6911-6 [PMID:8636118] 
56. Han X, Patters AB, Jones DP, Zelikovic I and Chesney RW. (2006) The taurine transporter: mechanisms of regulation. Acta Physiol (Oxf) 187: 61-73 [PMID:16734743]

57. Harvey RJ, Topf M, Harvey K and Rees MI. (2008) The genetics of hyperekplexia: more than startle! Trends Genet. 24: 439-47 [PMID:18707791]

58. Hatanaka T, Nakanishi T, Huang W, Leibach FH, Prasad PD, Ganapathy V and Ganapathy ME. (2001) $\mathrm{Na}+$ - and $\mathrm{Cl}$ - -coupled active transport of nitric oxide synthase inhibitors via amino acid transport system $\mathrm{B}(0,+)$. J. Clin. Invest. 107: 1035-43 [PMID:11306607]

59. Heffernan GD, Coghlan RD, Manas ES, McDevitt RE, Li Y, Mahaney PE, Robichaud AJ, Huselton C, Alfinito $P$ and Bray JA et al.. (2009) Dual acting norepinephrine reuptake inhibitors and 5-HT(2A) receptor antagonists: Identification, synthesis and activity of novel 4-aminoethyl-3-(phenylsulfonyl)-1H-indoles.

Bioorg. Med. Chem. 17: 7802-15 [PMID:19836247]

60. Heikkila RE and Manzino L. (1984) Behavioral properties of GBR 12909, GBR 13069 and GBR 13098 : specific inhibitors of dopamine uptake. Eur. J. Pharmacol. 103: 241-8 [PMID:6237922]

61. Heinrich T, Böttcher H, Gericke R, Bartoszyk GD, Anzali S, Seyfried CA, Greiner HE and Van Amsterdam C. (2004) Synthesis and structure--activity relationship in a class of indolebutylpiperazines as dual 5$\mathrm{HT}(1 \mathrm{~A})$ receptor agonists and serotonin reuptake inhibitors. J. Med. Chem. 47: 4684-92 [PMID:15341484]

62. Herdon HJ, Roberts JC, Coulton S and Porter RA. (2010) Pharmacological characterisation of the GlyT-1 glycine transporter using two novel radioligands. Neuropharmacology 59: 558-65 [PMID:20691713]

63. Inazu M, Takeda H, Ikoshi H, Sugisawa M, Uchida Y and Matsumiya T. (2001) Pharmacological characterization and visualization of the glial serotonin transporter. Neurochem. Int. 39: 39-49 [PMID:11311448]

64. Jensen NH, Rodriguiz RM, Caron MG, Wetsel WC, Rothman RB and Roth BL. (2008) Ndesalkylquetiapine, a potent norepinephrine reuptake inhibitor and partial 5-HT1A agonist, as a putative mediator of quetiapine's antidepressant activity. Neuropsychopharmacology 33: 2303-12 [PMID:18059438]

65. Jeong HJ, Vandenberg RJ and Vaughan CW. (2010) N-arachidonyl-glycine modulates synaptic transmission in superficial dorsal horn. Br. J. Pharmacol. 161: 925-35 [PMID:20860669]

66. Ju P, Aubrey KR and Vandenberg RJ. (2004) Zn2+ inhibits glycine transport by glycine transporter subtype 1b. J. Biol. Chem. 279: 22983-91 [PMID:15031290]

67. Karunakaran S, Umapathy NS, Thangaraju M, Hatanaka T, Itagaki S, Munn DH, Prasad PD and Ganapathy V. (2008) Interaction of tryptophan derivatives with SLC6A14 (ATB0,+) reveals the potential of the transporter as a drug target for cancer chemotherapy. Biochem. J. 414: 343-55 [PMID:18522536]

68. Kim DI, Deutsch HM, Ye X and Schweri MM. (2007) Synthesis and pharmacology of site-specific cocaine abuse treatment agents: restricted rotation analogues of methylphenidate. J. Med. Chem. 50: 2718-31 [PMID:17489581]

69. Knutsen LJ, Andersen KE, Lau J, Lundt BF, Henry RF, Morton HE, Naerum L, Petersen H, Stephensen H and Suzdak PD et al.. (1999) Synthesis of novel GABA uptake inhibitors. 3. Diaryloxime and diarylvinyl ether derivatives of nipecotic acid and guvacine as anticonvulsant agents. J. Med. Chem. 42: 3447-62 [PMID:10479278]

70. Kristensen AS, Andersen J, Jørgensen TN, Sørensen L, Eriksen J, Loland CJ, Strømgaard K and Gether U. (2011) SLC6 neurotransmitter transporters: structure, function, and regulation. Pharmacol. Rev. 63: 585-640 [PMID:21752877]

71. Kvist T, Christiansen B, Jensen AA and Bräuner-Osborne H. (2009) The four human gamma-aminobutyric acid (GABA) transporters: pharmacological characterization and validation of a highly efficient screening assay. Comb. Chem. High Throughput Screen. 12: 241-9 [PMID:19275529]

72. Lapinsky DJ, Aggarwal S, Huang Y, Surratt CK, Lever JR, Foster JD and Vaughan RA. (2009) A novel photoaffinity ligand for the dopamine transporter based on pyrovalerone. Bioorg. Med. Chem. 17: 3770-4 [PMID:19442525]

73. Lapinsky DJ, Velagaleti R, Yarravarapu N, Liu Y, Huang Y, Surratt CK, Lever JR, Foster JD, Acharya R and Vaughan RA et al.. (2011) Azido-iodo-N-benzyl derivatives of threo-methylphenidate (Ritalin, Concerta): Rational design, synthesis, pharmacological evaluation, and dopamine transporter photoaffinity 
labeling. Bioorg. Med. Chem. 19: 504-12 [PMID:21129986]

74. Li P, Zhang Q, Robichaud AJ, Lee T, Tomesch J, Yao W, Beard JD, Snyder GL, Zhu H and Peng Yet al.. (2014) Discovery of a tetracyclic quinoxaline derivative as a potent and orally active multifunctional drug candidate for the treatment of neuropsychiatric and neurological disorders. J. Med. Chem. 57: 2670-82 [PMID:24559051]

75. Liu H, Altenbach RJ, Carr TL, Chandran P, Hsieh GC, Lewis LG, Manelli AM, Milicic I, Marsh KC and Miller TR et al.. (2008) cis-4-(Piperazin-1-yl)-5,6,7a,8,9,10,11,11a-octahydrobenzofuro[2,3-h]quinazolin-2amine (A-987306), a new histamine H4R antagonist that blocks pain responses against carrageenaninduced hyperalgesia. J. Med. Chem. 51: 7094-8 [PMID:18983139]

76. Lowe 3rd JA, Drozda SE, Fisher K, Strick C, Lebel L, Schmidt C, Hiller D and Zandi KS. (2003) [3H]-(R)NPTS, a radioligand for the type 1 glycine transporter. Bioorg. Med. Chem. Lett. 13: 1291-2 [PMID:12657266]

77. Lowe 3rd JA, Hou X, Schmidt C, David Tingley 3rd F, McHardy S, Kalman M, Deninno S, Sanner M, Ward $\mathrm{K}$ and Lebel $\mathrm{L}$ et al.. (2009) The discovery of a structurally novel class of inhibitors of the type 1 glycine transporter. Bioorg. Med. Chem. Lett. 19: 2974-6 [PMID:19410451]

78. Madsen KK, White HS and Schousboe A. (2010) Neuronal and non-neuronal GABA transporters as targets for antiepileptic drugs. Pharmacol. Ther. 125: 394-401 [PMID:20026354]

79. Mallorga PJ, Williams JB, Jacobson M, Marques R, Chaudhary A, Conn PJ, Pettibone DJ and Sur C. (2003) Pharmacology and expression analysis of glycine transporter GlyT1 with [3H]-(N-[3-(4'fluorophenyl)-3-(4'phenylphenoxy)propyl])sarcosine. Neuropharmacology 45: 585-93 [PMID:12941372]

80. Maryanoff BE, McComsey DF, Castanzo MJ, Setler PE, Gardocki JF, Shank RP and Schneider CR. (1984) Pyrroloisoquinoline antidepressants. Potent, enantioselective inhibition of tetrabenazine-induced ptosis and neuronal uptake of norepinephrine, dopamine, and serotonin. J. Med. Chem. 27: 943-6 [PMID:6747993]

81. Melia KF and Spealman RD. (1991) Pharmacological characterization of the discriminative-stimulus effects of GBR 12909. J. Pharmacol. Exp. Ther. 258: 626-32 [PMID:1678014]

82. Mezler M, Hornberger W, Mueller R, Schmidt M, Amberg MS, Amberg W, Amberg MS, Braje W, Ochse M and Schoemaker $\mathrm{H}$ et al.. (2008) Inhibitors of GlyT1 affect glycine transport via discrete binding sites.Mol. Pharmacol. 74: 1705-15 [PMID:18815213]

83. Mladenova G, Annedi SC, Ramnauth J, Maddaford SP, Rakhit S, Andrews JS, Zhang D and Porreca F. (2012) First-in-class, dual-action, 3,5-disubstituted indole derivatives having human nitric oxide synthase (nNOS) and norepinephrine reuptake inhibitory (NERI) activity for the treatment of neuropathic pain. $J$. Med. Chem. 55: 3488-501 [PMID:22420844]

84. Newman AH, Kline RH, Allen AC, Izenwasser S, George C and Katz JL. (1995) Novel 4'-substituted and 4',4"-disubstituted 3 alpha-(diphenylmethoxy)tropane analogs as potent and selective dopamine uptake inhibitors. J. Med. Chem. 38: 3933-40 [PMID:7562926]

85. Núñez E, López-Corcuera B, Vázquez J, Giménez C and Aragón C. (2000) Differential effects of the tricyclic antidepressant amoxapine on glycine uptake mediated by the recombinant GLYT1 and GLYT2 glycine transporters. Br. J. Pharmacol. 129: 200-6 [PMID:10694221]

86. O'Neill DJ, Adedoyin A, Alfinito PD, Bray JA, Cosmi S, Deecher DC, Fensome A, Harrison J, Leventhal L and Mann $C$ et al.. (2010) Discovery of novel selective norepinephrine reuptake inhibitors: 4-[3-aryl-2,2dioxido-2,1,3-benzothiadiazol-1(3H)-yl]-1-(methylamino)butan-2-ols (WYE-103231). J. Med. Chem. 53: 4511-21 [PMID:20462211]

87. Owens MJ, Morgan WN, Plott SJ and Nemeroff CB. (1997) Neurotransmitter receptor and transporter binding profile of antidepressants and their metabolites. J. Pharmacol. Exp. Ther. 283: 1305-22 [PMID:9400006]

88. Pearlman RJ, Aubrey KR and Vandenberg RJ. (2003) Arachidonic acid and anandamide have opposite modulatory actions at the glycine transporter, GLYT1a. J. Neurochem. 84: 592-601 [PMID:12558979]

89. Pechulis AD, Beck JP, Curry MA, Wolf MA, Harms AE, Xi N, Opalka C, Sweet MP, Yang Z and Vellekoop AS et al.. (2012) 4-Phenyl tetrahydroisoquinolines as dual norepinephrine and dopamine reuptake 
inhibitors. Bioorg. Med. Chem. Lett. 22: 7219-22 [PMID:23084899]

90. Pinard E, Alanine A, Alberati D, Bender M, Borroni E, Bourdeaux P, Brom V, Burner S, Fischer $\mathrm{H}$ and Hainzl D et al.. (2010) Selective GlyT1 inhibitors: discovery of [4-(3-fluoro-5-trifluoromethylpyridin-2yl)piperazin-1-yl][5-methanesulfonyl-2-((S)-2,2,2-trifluoro-1-methylethoxy)phenyl]methanone (RG1678), a promising novel medicine to treat schizophrenia. J. Med. Chem. 53: 4603-14 [PMID:20491477]

91. Pochini L, Seidita A, Sensi C, Scalise M, Eberini I and Indiveri C. (2014) Nimesulide binding site in the B0AT1 (SLC6A19) amino acid transporter. Mechanism of inhibition revealed by proteoliposome transport assay and molecular modelling. Biochem. Pharmacol. 89: 422-30 [PMID:24704252]

92. Pristupa ZB, Wilson JM, Hoffman BJ, Kish SJ and Niznik HB. (1994) Pharmacological heterogeneity of the cloned and native human dopamine transporter: disassociation of [3H]WIN 35,428 and [3H]GBR 12,935 binding. Mol. Pharmacol. 45: 125-35 [PMID:8302271]

93. Pérez-Siles G, Morreale A, Leo-Macías A, Pita G, Ortíz AR, Aragón C and López-Corcuera B. (2011) Molecular basis of the differential interaction with lithium of glycine transporters GLYT1 and GLYT2. J. Neurochem. 118: 195-204 [PMID:21574997]

94. Raffel DM and Chen W. (2004) Binding of [3H]mazindol to cardiac norepinephrine transporters: kinetic and equilibrium studies. Naunyn Schmiedebergs Arch. Pharmacol. 370: 9-16 [PMID:15300361]

95. Reith ME, Xu C, Zhang L and Coffey LL. (1996) Translocation of dopamine and binding of WIN 35,428 measured under identical conditions in cells expressing the cloned human dopamine transporter. Naunyn Schmiedebergs Arch. Pharmacol. 354: 295-304 [PMID:8878059]

96. Rotella DP, McFarlane GR, Greenfield A, Grosanu C, Robichaud AJ, Denny RA, Feenstra RW, NúñezGarcía S, Reinders JH and Neut Mv et al.. (2009) Tetrahydrocarbazole-based serotonin reuptake inhibitor/dopamine D2 partial agonists for the potential treatment of schizophrenia. Bioorg. Med. Chem. Lett. 19: 5552-5 [PMID:19720528]

97. Rousseau F, Aubrey KR and Supplisson S. (2008) The glycine transporter GlyT2 controls the dynamics of synaptic vesicle refilling in inhibitory spinal cord neurons. J. Neurosci. 28: 9755-68 [PMID:18815261]

98. Sabatucci JP, Mahaney PE, Leiter J, Johnston G, Burroughs K, Cosmi S, Zhang Y, Ho D, Deecher DC and Trybulski E. (2010) Heterocyclic cycloalkanol ethylamines as norepinephrine reuptake inhibitors. Bioorg. Med. Chem. Lett. 20: 2809-12 [PMID:20378347]

99. Saier MH, Yen MR, Noto K, Tamang DG and Elkan C. (2009) The Transporter Classification Database: recent advances. Nucleic Acids Res. 37: D274-8 [PMID:19022853]

100. Schousboe A, Madsen KK and White HS. (2011) GABA transport inhibitors and seizure protection: the past and future. Future Med Chem 3: 183-7 [PMID:21428813]

101. Schousboe A, Sarup A, Larsson OM and White HS. (2004) GABA transporters as drug targets for modulation of GABAergic activity. Biochem. Pharmacol. 68: 1557-63 [PMID:15451399]

102. Semyanov A, Walker MC, Kullmann DM and Silver RA. (2004) Tonically active GABA A receptors: modulating gain and maintaining the tone. Trends Neurosci. 27: 262-9 [PMID:15111008]

103. Shobo M, Kondo Y, Yamada H, Mihara T, Yamamoto N, Katsuoka M, Harada K, Ni K and Matsuoka N. (2010) Norzotepine, a major metabolite of zotepine, exerts atypical antipsychotic-like and antidepressantlike actions through its potent inhibition of norepinephrine reuptake. J. Pharmacol. Exp. Ther. 333: 772-81 [PMID:20223878]

104. Singer D, Camargo SM, Huggel K, Romeo E, Danilczyk U, Kuba K, Chesnov S, Caron MG, Penninger JM and Verrey F. (2009) Orphan transporter SLC6A18 is renal neutral amino acid transporter B0AT3. J. Biol. Chem. 284: 19953-60 [PMID:19478081]

105. Singh SK, Yamashita A and Gouaux E. (2007) Antidepressant binding site in a bacterial homologue of neurotransmitter transporters. Nature 448: 952-6 [PMID:17687333]

106. Sloan $\mathrm{JL}$ and Mager S. (1999) Cloning and functional expression of a human $\mathrm{Na}(+)$ and $\mathrm{Cl}(-)$-dependent neutral and cationic amino acid transporter B(0+). J. Biol. Chem. 274: 23740-5 [PMID:10446133]

107. Snyder GL, Vanover KE, Zhu H, Miller DB, O'Callaghan JP, Tomesch J, Li P, Zhang Q, Krishnan V and Hendrick JP et al.. (2015) Functional profile of a novel modulator of serotonin, dopamine, and glutamate neurotransmission. Psychopharmacology (Berl.) 232: 605-21 [PMID:25120104] 
108. Supplisson S and Roux MJ. (2002) Why glycine transporters have different stoichiometries.FEBS Lett. 529: 93-101 [PMID:12354619]

109. Sweetnam PM, Caldwell L, Lancaster J, Bauer Jr C, McMillan B, Kinnier WJ and Price CH. (1993) The role of receptor binding in drug discovery. J. Nat. Prod. 56: 441-55 [PMID:8496700]

110. Talvenheimo J, Fishkes H, Nelson PJ and Rudnick G. (1983) The serotonin transporter-imipramine "receptor". J. Biol. Chem. 258: 6115-9 [PMID:6853478]

111. Tatsumi M, Groshan K, Blakely RD and Richelson E. (1997) Pharmacological profile of antidepressants and related compounds at human monoamine transporters. Eur. J. Pharmacol. 340: 249-58 [PMID:9537821]

112. Thomsen C, Sørensen PO and Egebjerg J. (1997) 1-(3-(9H-carbazol-9-yl)-1-propyl)-4-(2-methoxyphenyl)4-piperidinol, a novel subtype selective inhibitor of the mouse type II GABA-transporter. Br. J. Pharmacol. 120: 983-5 [PMID:9134205]

113. Trenchard A, Turner P, Pare CM and Hills M. (1975) The effects of protriptyline and clomipramine in vitro on the uptake of 5-hydroxytryptamine and dopamine in human platelet-rich plasma. Psychopharmacologia 43: 89-93 [PMID:1161997]

114. Tsai G, Ralph-Williams RJ, Martina M, Bergeron R, Berger-Sweeney J, Dunham KS, Jiang Z, Caine SB and Coyle JT. (2004) Gene knockout of glycine transporter 1: characterization of the behavioral phenotype. Proc. Natl. Acad. Sci. U.S.A. 101: 8485-90 [PMID:15159536]

115. Tzschentke TM, Christoph T, Kögel B, Schiene K, Hennies HH, Englberger W, Haurand M, Jahnel U, Cremers $\mathrm{TI}$ and Friderichs E et al.. (2007) (-)-(1R,2R)-3-(3-dimethylamino-1-ethyl-2-methyl-propyl)-phenol hydrochloride (tapentadol $\mathrm{HCl}$ ): a novel mu-opioid receptor agonist/norepinephrine reuptake inhibitor with broad-spectrum analgesic properties. J. Pharmacol. Exp. Ther. 323: 265-76 [PMID:17656655]

116. Umapathy NS, Ganapathy V and Ganapathy ME. (2004) Transport of amino acid esters and the aminoacid-based prodrug valganciclovir by the amino acid transporter ATB $(0,+)$. Pharm. Res. 21: 1303-10 [PMID:15290873]

117. Van Orden LJ, Van Dyke PM, Saito DR, Church TJ, Chang R, Smith JA, Martin WJ, Jaw-Tsai S and Stangeland EL. (2013) A novel class of 3-(phenoxy-phenyl-methyl)-pyrrolidines as potent and balanced norepinephrine and serotonin reuptake inhibitors: synthesis and structure-activity relationships. Bioorg. Med. Chem. Lett. 23: 1456-61 [PMID:23347683]

118. Vandenberg RJ, Ju P, Aubrey KR, Ryan RM and Mitrovic AD. (2004) Allosteric modulation of neurotransmitter transporters at excitatory synapses. Eur J Pharm Sci 23: 1-11 [PMID:15324920]

119. Vandenberg RJ, Shaddick K and Ju P. (2007) Molecular basis for substrate discrimination by glycine transporters. J. Biol. Chem. 282: 14447-53 [PMID:17383967]

120. Vanslambrouck JM, Bröer A, Thavyogarajah T, Holst J, Bailey CG, Bröer S and Rasko JE. (2010) Renal imino acid and glycine transport system ontogeny and involvement in developmental iminoglycinuria. Biochem. J. 428: 397-407 [PMID:20377526]

121. Vickers T, Dyck B, Tamiya J, Zhang M, Jovic F, Grey J, Fleck BA, Aparicio A, Johns M and Jin let al.. (2008) Studies on a series of milnacipran analogs containing a heteroaromatic group as potent norepinephrine and serotonin transporter inhibitors. Bioorg. Med. Chem. Lett. 18: 3230-5 [PMID:18468895]

122. White HS, Watson WP, Hansen SL, Slough S, Perregaard J, Sarup A, Bolvig T, Petersen G, Larsson OM and Clausen RP et al.. (2005) First demonstration of a functional role for central nervous system betaine/\{gamma\}-aminobutyric acid transporter (mGAT2) based on synergistic anticonvulsant action among inhibitors of mGAT1 and mGAT2. J. Pharmacol. Exp. Ther. 312: 866-74 [PMID:15550575]

123. Wiles AL, Pearlman RJ, Rosvall M, Aubrey KR and Vandenberg RJ. (2006) N-Arachidonyl-glycine inhibits the glycine transporter, GLYT2a. J. Neurochem. 99: 781-6 [PMID:16899062]

124. Wong EH, Sonders MS, Amara SG, Tinholt PM, Piercey MF, Hoffmann WP, Hyslop DK, Franklin S, Porsolt RD and Bonsignori A et al.. (2000) Reboxetine: a pharmacologically potent, selective, and specific norepinephrine reuptake inhibitor. Biol. Psychiatry 47: 818-29 [PMID:10812041]

125. Xu X, Wei Y, Guo Q, Zhao S, Liu Z, Xiao T, Liu Y, Qiu Y, Hou Y and Zhang @et al.. (2018) Pharmacological Characterization of $\mathrm{H05}$, a Novel Serotonin and Noradrenaline Reuptake Inhibitor with 
Moderate 5- $\mathrm{HT}_{2 \mathrm{~A}}$ Antagonist Activity for the Treatment of Depression.J. Pharmacol. Exp. Ther. 365: 624635 [PMID:29615471]

126. Yamashita A, Singh SK, Kawate T, Jin Y and Gouaux E. (2005) Crystal structure of a bacterial homologue of $\mathrm{Na}+/ \mathrm{Cl}-$-dependent neurotransmitter transporters. Nature 437: 215-23 [PMID:16041361]

127. Yee BK, Balic E, Singer P, Schwerdel C, Grampp T, Gabernet L, Knuesel I, Benke D, Feldon J and Mohler $\mathrm{H}$ et al.. (2006) Disruption of glycine transporter 1 restricted to forebrain neurons is associated with a procognitive and antipsychotic phenotypic profile. J. Neurosci. 26: 3169-81 [PMID:16554468]

128. Yu XC, Zhang W, Oldham A, Buxton E, Patel S, Nghi N, Tran D, Lanthorn TH, Bomont C and Shi ZCet al.. (2009) Discovery and characterization of potent small molecule inhibitors of the high affinity proline transporter. Neurosci. Lett. 451: 212-6 [PMID:19159658]

129. Zaia KA and Reimer RJ. (2009) Synaptic Vesicle Protein NTT4/XT1 (SLC6A17) Catalyzes Na+-coupled Neutral Amino Acid Transport. J. Biol. Chem. 284: 8439-48 [PMID:19147495]

130. Zeng Z, O'Brien JA, Lemaire W, O'Malley SS, Miller PJ, Zhao Z, Wallace MA, Raab C, Lindsley CW and Sur $C$ et al.. (2008) A novel radioligand for glycine transporter 1: characterization and use in autoradiographic and in vivo brain occupancy studies. Nucl. Med. Biol. 35: 315-25 [PMID:18355687]

131. Zhang HX, Hyrc K and Thio LL. (2009) The glycine transport inhibitor sarcosine is an NMDA receptor coagonist that differs from glycine. J. Physiol. (Lond.) 587: 3207-20 [PMID:19433577]

132. Zhang P, Jørgensen TN, Loland CJ and Newman AH. (2013) A rhodamine-labeled citalopram analogue as a high-affinity fluorescent probe for the serotonin transporter. Bioorg. Med. Chem. Lett. 23: 323-6 [PMID:23168018]

133. Zhou J, He R, Johnson KM, Ye Y and Kozikowski AP. (2004) Piperidine-based nocaine/modafinil hybrid ligands as highly potent monoamine transporter inhibitors: efficient drug discovery by rational lead hybridization. J. Med. Chem. 47: 5821-4 [PMID:15537337]

134. Zipp GG, Barbosa J, Green MA, Terranova KM, Fink C, Yu XC, Nouraldeen A, Wilson A, Savelieva K and Lanthorn TH et al.. (2014) Novel inhibitors of the high-affinity L-proline transporter as potential therapeutic agents for the treatment of cognitive disorders. Bioorg. Med. Chem. Lett. 24: 3886-90 [PMID:25037917] 